\title{
Grammatical Errors in the Expository Essays of Public Health Students of Njala University
}

\author{
Saidu Challay (Corresponding author) \\ Institute of Languages and Cultural Studies \\ Njala University, Sierra Leone
}

Tel: 232-76-428 532 E-mail: s_challay@njala.edu.sl

\author{
Vandi S. Kanneh \\ Institute of Languages and Cultural Studies \\ Njala University, Sierra Leone
}

Tel: 232-76-796 590 E-mail: vandikanneh@gmail.com

Received: December 3, 2021

doi:10.5296/ijl.v14i1.19470
Accepted: January 9, 2022 Published: January 17, 2022

URL: https://doi.org/10.5296/ijl.v14i1.19470

\begin{abstract}
The purpose of this study was to identify and analyse the grammatical errors in the expository essay of second year students pursuing a programme of study leading to the Bachelor of Science degree in Public Health at the Njala University, Bo Campus. 100 students were randomly selected from among 190 students of the same class who wrote the test on a subject matter that falls within their domain. Errors were identified and categorized into ten: verb usage, noun usage, punctuation marks, spellings, wrong words, capitalization, pronoun usage, prepositions, abbreviations/coinages and articles. To ascertain the percentage and mean score of each error category, descriptive statistics was used. Using this criterion, five error areas: verb usage, punctuation marks, spellings, wrong words and capitalisation were identified to be significant because of mean scores exceeding 2.0 in each case. The remaining error categories were not significant but show that the students have problem using them correctly in expressing their ideas in written form. Most of the errors made were as a result of overgeneralisation of grammatical rules, $\mathrm{L}_{1}$ interference and ignorance of many rules of English Grammar, and the inability of second language learners to construct the forms of the target language because of inadequate exposure to the target language. These error problems would only be overcome if the learners are adequately exposed to the grammar of English
\end{abstract}


from primary school to university, and if they also adopt favourable attitude towards the learning of English.

Keywords: Error analysis, Grammatical errors, Official language, Target language

\section{Introduction}

English language remains to be one of the most dominant languages in Sierra Leone as well as other former British colonies. It is arguably the world's most important language as it is used as an official language in many countries across the globe. In Nigeria for example, English is the language of government, of commerce, of the legislature and as a means of communication among Nigerians from different ethnic backgrounds (Lagu, 2019). The role that English plays in Sierra Leone is so diverse, which include the following: medium of instruction throughout the educational system, used in government functionaries, international trade and communication, mass media, and science and technology. Thus, English has remained to be the country's official language since independence. Various authors have commented on the dominant role that the language plays. Gut (2013:213) for example states that 'English is spoken in the Anglophone countries in a highly multilingual setting, and it enjoys an important status as an official or national language. It also functions as the language of government, law, business and commerce, education and media'. The importance of English in the educational system of post-colonial countries is that it has remained to be a compulsory subject and pre-requisite for attaining further studies at the tertiary level. All candidates aspiring for tertiary education are required to have a credit pass in English or better.

In spite of the significant role that English plays in Sierra Leone and many other countries where English is used a second or foreign language, the teaching and learning of the language has been characterized by several problems ranging from negative attitude of learners, unavailability of teaching and learning materials, transfer of $\mathrm{L}_{1}$ rules into the target language, and in some cases teachers' lack of competence in $\mathrm{L}_{2}$ teaching process (Pouladian et. al., 2017; Sowa, 2017). Other studies further reveal that the teaching of English has been affected by factors such as lack of equipment, lack of motivation on the part of both the teachers and learners, and insufficient allocation of the teaching hours (Udom, 2014). What seems to have compounded the problem further is the advent of social media, which has to some extent very negatively impacted on the writing skills of most learners. Gomina (2014) states that the influence of SMS messages in the writing of most Nigerian students could be felt in the following areas; spelling mistakes, poor expression, low intelligibility, poor performance in mechanical accuracy and semantic implications. Most of the times students become so accustomed to form writing adopted whilst sending and replying to SMS messages, and are often tempted to use these forms when they are given a writing task. In order to address this anomaly, Gomina (2014) recommends that English Language teachers need to be mindful about this problem, and take urgent action to prevent a continuation of this awkward trend.

Sermsook et. al. (2016) analysed the errors of 26 second-year English major students in the Writing II in Thailand, and discovered six main types of errors most frequently made by the participants. These errors included punctuation marks, articles, subject-verb agreement, 
spelling, capitalisation, and fragments. In a similar study by Abushihab (2014), 20 Turkish second-year student were given a writing exercise in order to analyse their errors. The total number of grammatical errors were 179, and included the following; tense (15\%), prepositions (28\%), articles (29\%), active and passive voice (9.5\%) and morphology (18.4\%) (Abushihab, 2014:216). Based on this, it becomes evident that $\mathrm{L}_{2}$ learners face a lot of difficulties in writing compositions in English. Part of this difficulty could be as a result of what Lado (1957) perceived as the $\mathrm{L}_{2}$ learner bringing to his/her task a repertoire of $\mathrm{L}_{1}$ habits. This had serious implications in the teaching and learning of second languages. Contrastive Analysis was a preferred paradigm in the study of errors in the 1950s and 1960s as it sought to make comparisons between two or more languages to determine the similarities and differences between such languages. (James, 2001). This approach to the study of errors made by learners however became unpopular among second language researchers as most of the predictions made relating to the causes of errors did not in most cases turn out to be true. The predictive nature of contrastive analysis became contested later, and as such Error Analysis emerged in the sixties, and it became clear that learner errors were not entirely as a result of the differences between the learner's $\mathrm{L}_{1}$ and the target language.

In a study by Lagu (2019), 100 participants were randomly selected among 400 level students to write an essay on a given task in order to find out the type of errors that learners at this level were likely to commit. Results from the study showed that $32.2 \%$ of the errors were in the use of verbs, 5.8\% were spelling errors, errors in the wrong form of words was $18.6 \%$, errors in noun forms $7.5 \%$, errors in the use of pronouns $5.3 \%$, errors in the use of articles $4.9 \%$, errors in the use of prepositions $4.6 \%$, errors in abbreviation/coinage $0.8 \%$ and errors in punctuation and capitalisation 12.6\%. (Lagu 2019:187-191). The highest number of errors were in the area of verb usage, which has to do with tenses, subject-verb agreement, modal auxiliaries etc. This calls for great attention by teachers of English, as learners' competencies in this area are very key for them to communicate effectively in the language.

Several studies in the 1960s and early 1970s developed great interest in the systematic nature of learner errors. For most of these studies, learner errors were not considered to be random mistakes, but rather represented an evidence of rule-governed behaviour (Corder 1976); Nemser 1971; Selinker 1972).

English use and usage poses a serious problem for learners in tertiary institutions of Sierra Leone. This study was specifically designed to identify some of the problems learners at the tertiary education face in the area of English grammar and usage.

\section{Aim and Objectives}

The aim of this study is to carry out an analysis of the grammatical errors in the essays of Public Health students of Njala University.

The specific objectives of the study include the following:

1. To determine the nature of errors committed by students pursuing Public Health.

2. To identify and examine the various types of grammatical errors in the writing of 
Public Health students.

3. To identify and examine the possible causes of these errors.

4. To proffer suggestions that would help improve the writing skills of students.

\section{Theoretical Framework}

The theoretical framework adopted for this study is based on Error Analysis. Linguists and language teachers have always developed keen interest in errors produced by second language learners, either in the written or spoken form or both. This is because learners' errors are a source of information that guides teachers as to the progress learners are making in learning a second language. Error Analysis has emerged as one of the most important areas in the field of Linguistics. Jabeen et al. (2015) stressed that error making is not bad all the times, yet they are important aspects that guide the learner and teacher in the process of learning a language. Different types of errors are expected to be made by $\mathrm{L}_{2}$ learners as they progress. The different levels of errors made by learners show that a beginning $\mathrm{L}_{2}$ learner is expected to be influenced by his $\mathrm{L}_{1}$ than an intermediate $\mathrm{L} 2$ learner who has been adequately exposed to the $\mathrm{L}_{2}$ for long (Feltsen, 2009). However, Al-Kresheh (2016) attempted to explain the various error analysis theories that seek to explain why errors occur and how they are remedied. In his explanation, two theories which resonate with this research were identified: the Behaviouristic and the Contrastive Analysis Hypothesis put forward by Lado. Until the late sixties, the field of $\mathrm{L}_{2}$ learning was purely behaviouristic. This theory proved that language learning was an outcome of the acquisition of new language patterns. This means that $\mathrm{L}_{2}$ errors were made because of the learners' $\mathrm{L}_{1}$. Also, Contrastive Analysis Hypothesis was a theory which became widely known because of its ability to compare structures of two languages with the view to identifying the similarities and differences between the target language and the $\mathrm{L}_{1}$. Structures in the target language that are similar to the $\mathrm{L}_{1}$ are easy to learn whereas structures that are not the same are difficult to learn. Therefore, Valcea (2020) argued that when second language learners transfer their knowledge of the grammar of their $\mathrm{L}_{1}$ into $\mathrm{L}_{2}$ learning, errors are bound to occur because of the language differences between the $\mathrm{L}_{1}$ and the $\mathrm{L}_{2}$. Corder (1967) clearly presents the role of errors in second language learning when he argues that language errors made by learners is an indication of their attempt to organize their linguistic competence. Learner errors are therefore very important in the process of learning a second language. Thus, error analysis basically deals with identifying, describing and explaining errors of language learners.

As earlier claimed by proponents of Contrastive Analysis, interference from the mother-tongue is not the only source of errors in $\mathrm{L}_{2}$ learning. Richards (1971; cited in Khansir 2012) classified errors into four groups as follows: overgeneralisation, ignorance of rule restriction, incomplete application of rules and false concepts hypothesized.

\section{Method}

This study adopted the descriptive method as the aim of the study was to identify and analyse the errors in the written essays of students in the Public Health Department at the Njala University. This method is preferred because it usually provides naturally occurring sentences 


\section{Macrothink}

International Journal of Linguistics

ISSN 1948-5425

2022, Vol. 14, No. 1

of the participants. Descriptive statistics was also used in the analysis, and this helped in describing, presenting and summarising data in a logical and meaningful way.

\subsection{Participants}

For the purpose of data collection, 100 students in the second year of their four-year programme pursuing Bachelor of Science in Public Health at the School of Community Health Sciences, Njala University were randomly selected to participate in the study.

\subsection{Instrument}

The main instrument used for data collection was an expository essay on the topic: Discuss how COVID-19 has affected the livelihoods of people in your country. The participants were asked to write an essay of 450 words long, so that the grammatical errors contained in those essays could be identified and analysed.

\subsection{Procedure for Data Collection}

Before conducting the test, permission was sought from the Head of Department as well as the students concerned to carry out the research in the department. The students were briefed about the purpose of the research, and they were given clear instructions about what they were expected to do. The Head of Department was asked to permit the 100 students to write an essay in 50 minutes on the topic: Discuss how COVID-19 has affected the livelihoods of people in your country. The aim was to identify all grammatical errors in the areas of verbs and verb usage, nouns and their usage, punctuation marks, spellings, wrong words or registers, capitalisation, pronouns and their usage, prepositions, abbreviation/coinages and articles in their written essays.

\section{Results}

At the end of the test, the 100 scripts were marked, and the following areas of grammar were identified as areas where grammatical errors were committed by the students: verbs and verb usage, nouns and their usage, punctuation marks, spellings, wrong words or registers, capitalisation, pronouns and their usage, prepositions, abbreviation/coinages and articles.

The table that follows presents an analysis of all the errors in the written essays of the participants in the study. 
Table 1. Classification of errors and their frequency in the students' essays

\begin{tabular}{|c|c|c|c|c|c|c|c|c|c|c|}
\hline 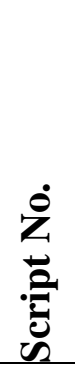 & 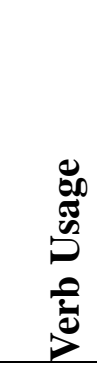 & 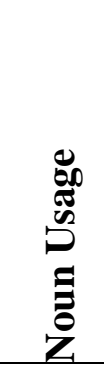 & & & 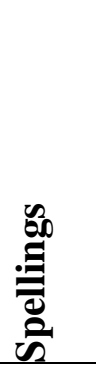 & 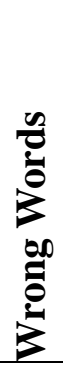 & 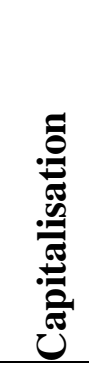 & 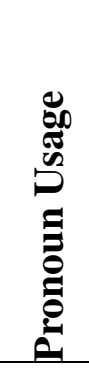 & : & \\
\hline 1 & 9 & 5 & 9 & 1 & 1 & 9 & - & 2 & 1 & 2 \\
\hline 2 & 3 & - & 8 & 3 & 6 & 7 & - & 1 & - & - \\
\hline 3 & 3 & 1 & 9 & 6 & 4 & 8 & 1 & 2 & - & 1 \\
\hline 4 & 5 & 2 & 4 & 3 & 5 & 9 & - & - & - & 2 \\
\hline 5 & 8 & - & 8 & 5 & 3 & 4 & - & 1 & - & 2 \\
\hline 6 & 2 & 2 & 8 & 5 & 9 & 1 & - & - & - & 1 \\
\hline 7 & 7 & - & 4 & 9 & 8 & 3 & - & 2 & - & 1 \\
\hline 8 & 9 & 2 & - & 2 & 3 & 5 & - & 1 & - & - \\
\hline 9 & - & 3 & - & 2 & 1 & 1 & - & - & - & 1 \\
\hline 10 & 4 & - & 1 & - & 3 & 1 & - & 1 & - & - \\
\hline 11 & 8 & - & 2 & 9 & 8 & 5 & - & 1 & - & 1 \\
\hline 12 & 2 & 1 & - & 9 & 6 & - & - & - & - & - \\
\hline 13 & 4 & 1 & 3 & 8 & 4 & 9 & - & 2 & - & - \\
\hline 14 & 6 & 4 & 5 & 7 & 6 & - & - & 1 & - & - \\
\hline 15 & 8 & 1 & 6 & - & 3 & - & - & 2 & - & - \\
\hline 16 & 4 & 1 & 4 & 8 & 7 & 3 & - & 8 & - & 2 \\
\hline 17 & 2 & - & 4 & 1 & 3 & - & 1 & 2 & - & 1 \\
\hline 18 & 4 & 2 & 8 & 2 & 1 & 9 & - & - & - & 2 \\
\hline 19 & 9 & - & 6 & 8 & 1 & - & - & 1 & - & - \\
\hline 20 & 3 & - & 9 & - & - & 4 & - & - & - & - \\
\hline 21 & 4 & - & 5 & 3 & 1 & 9 & - & - & - & - \\
\hline 22 & 4 & 2 & 7 & 1 & 2 & 1 & - & - & - & - \\
\hline 23 & 3 & 2 & 7 & 8 & 3 & 5 & - & - & - & 1 \\
\hline 24 & 4 & 2 & 8 & 2 & 6 & 3 & - & 1 & - & 2 \\
\hline 25 & 5 & - & 10 & - & 2 & 9 & 5 & 3 & - & 1 \\
\hline 26 & 1 & - & 6 & 9 & 2 & 2 & - & - & - & - \\
\hline 27 & 3 & - & 1 & 8 & 2 & 3 & - & 1 & - & - \\
\hline 28 & 6 & 1 & 7 & 4 & 5 & 3 & - & 4 & - & 1 \\
\hline 29 & 3 & 3 & 9 & 2 & 6 & 3 & - & 2 & - & - \\
\hline 30 & 1 & - & 6 & 1 & 4 & 2 & - & - & - & - \\
\hline 31 & 7 & 1 & 5 & 3 & - & 1 & - & - & - & 1 \\
\hline 32 & 2 & - & 5 & 2 & - & 4 & - & 1 & - & - \\
\hline 33 & 5 & 2 & 5 & 3 & - & 3 & 1 & 2 & - & 1 \\
\hline
\end{tabular}




\begin{tabular}{|c|c|c|c|c|c|c|c|c|c|c|c|}
\hline 34 & 5 & 1 & 7 & 3 & - & 3 & - & - & - & - & 19 \\
\hline 35 & 2 & - & 11 & - & 2 & 4 & - & 1 & - & 1 & 21 \\
\hline 36 & 8 & - & 10 & 1 & 1 & - & - & 2 & - & - & 22 \\
\hline 37 & 5 & 7 & 3 & 1 & 6 & 5 & - & 2 & - & - & 29 \\
\hline 38 & 3 & - & 9 & 3 & 2 & - & - & - & - & 1 & 18 \\
\hline 39 & 4 & - & 9 & 2 & 2 & - & - & 2 & - & - & 19 \\
\hline 40 & 3 & - & 8 & 3 & 5 & 9 & - & - & - & - & 28 \\
\hline 41 & 4 & - & 3 & 6 & - & 6 & - & - & - & - & 19 \\
\hline 42 & 6 & - & 4 & 10 & 3 & 4 & - & - & - & - & 27 \\
\hline 43 & 8 & - & 7 & 7 & 7 & 8 & - & - & - & - & 37 \\
\hline 44 & 4 & 3 & 4 & - & - & 6 & 1 & 1 & - & 1 & 20 \\
\hline 45 & 10 & 3 & 4 & 1 & 8 & 3 & - & 2 & - & 2 & 33 \\
\hline 46 & 6 & - & 1 & 3 & 8 & 4 & 2 & 4 & - & - & 28 \\
\hline 47 & 2 & 2 & 3 & 3 & 5 & 4 & - & 1 & - & - & 20 \\
\hline 48 & 7 & 6 & 1 & 9 & 5 & 10 & 1 & 4 & - & 1 & 44 \\
\hline 49 & 4 & 2 & 10 & 4 & 3 & 9 & - & 5 & - & - & 37 \\
\hline 50 & 3 & 1 & 3 & - & 3 & 5 & - & 5 & - & - & 20 \\
\hline 51 & 1 & 3 & 9 & 1 & 3 & 1 & - & 1 & - & 2 & 21 \\
\hline 52 & 4 & - & 3 & 3 & - & 5 & 1 & - & - & - & 16 \\
\hline 53 & 2 & - & 4 & 3 & 2 & 3 & - & 1 & - & - & 15 \\
\hline 54 & 5 & - & 4 & 8 & 9 & 10 & 3 & 1 & - & - & 40 \\
\hline 55 & 10 & 7 & 9 & 2 & 4 & 9 & 3 & 3 & - & 2 & 49 \\
\hline 56 & - & - & 3 & - & 3 & - & 2 & - & - & - & 08 \\
\hline 57 & 8 & 1 & 8 & 2 & 5 & 7 & 1 & 1 & - & 1 & 34 \\
\hline 58 & 4 & - & - & 1 & 2 & - & - & - & - & - & 07 \\
\hline 59 & 2 & 2 & - & 5 & 2 & - & - & 1 & - & - & 12 \\
\hline 60 & 2 & - & 7 & 1 & 3 & 7 & 3 & 1 & - & - & 24 \\
\hline 61 & - & 1 & 2 & 1 & 1 & 2 & - & - & - & - & 07 \\
\hline 62 & 3 & 1 & 1 & 2 & 6 & 3 & - & 1 & - & 1 & 18 \\
\hline 63 & 1 & - & 3 & 1 & - & 9 & - & - & - & - & 14 \\
\hline 64 & 4 & - & 4 & 3 & 4 & - & 1 & 1 & - & - & 17 \\
\hline 65 & 4 & - & 1 & 3 & 2 & 9 & - & - & - & 1 & 20 \\
\hline 66 & 8 & 2 & 3 & 4 & 6 & 3 & 1 & - & - & - & 27 \\
\hline 67 & 1 & - & - & 4 & 5 & 5 & 1 & 1 & - & - & 17 \\
\hline 68 & 3 & 2 & 1 & 6 & 6 & 3 & 3 & - & - & 4 & 28 \\
\hline 69 & 4 & - & 4 & 3 & 4 & 6 & 3 & 1 & - & 1 & 26 \\
\hline 70 & - & - & 3 & 8 & 9 & 6 & - & 3 & - & - & 29 \\
\hline 71 & - & 3 & 9 & 3 & 10 & 2 & - & 1 & - & - & 28 \\
\hline 72 & 2 & - & 3 & - & 2 & 4 & 2 & 1 & - & - & 14 \\
\hline 73 & 9 & 1 & 1 & 5 & 4 & 5 & - & - & - & - & 25 \\
\hline 74 & 5 & - & 1 & - & - & 6 & - & - & 1 & - & 13 \\
\hline 75 & 4 & - & 4 & 3 & 4 & 1 & - & 1 & - & - & 17 \\
\hline
\end{tabular}




\begin{tabular}{|c|c|c|c|c|c|c|c|c|c|c|c|}
\hline 76 & 3 & - & - & 3 & 4 & 5 & 1 & - & - & - & 16 \\
\hline 77 & 5 & - & 3 & - & 3 & 6 & - & - & - & - & 17 \\
\hline 78 & 2 & - & 9 & 3 & 4 & 3 & - & - & - & - & 21 \\
\hline 79 & 6 & 1 & 9 & 6 & 2 & 10 & - & 5 & - & - & 39 \\
\hline 80 & 3 & - & 3 & - & 6 & 2 & - & - & - & - & 14 \\
\hline 81 & - & 1 & 9 & 7 & 11 & 3 & - & 1 & - & 1 & 33 \\
\hline 82 & 3 & 2 & 6 & 5 & 5 & 3 & 2 & - & - & - & 26 \\
\hline 83 & 3 & 6 & 7 & 2 & 1 & 1 & 2 & 3 & - & - & 25 \\
\hline 84 & - & - & 8 & 3 & 4 & 1 & 2 & 2 & - & 1 & 21 \\
\hline 85 & 3 & - & 4 & 3 & 4 & 1 & 2 & 3 & - & - & 20 \\
\hline 86 & 4 & 5 & 3 & 7 & 6 & 2 & - & 2 & - & - & 29 \\
\hline 87 & 2 & - & 2 & 3 & 2 & 7 & 2 & - & - & - & 18 \\
\hline 88 & 3 & 3 & 2 & 5 & 2 & 7 & 3 & - & - & - & 25 \\
\hline 89 & 2 & - & - & 3 & 5 & 2 & 1 & - & - & - & 13 \\
\hline 90 & - & 2 & 3 & 5 & 1 & 1 & - & - & - & - & 12 \\
\hline 91 & 4 & 2 & 4 & 6 & 7 & 4 & 3 & - & - & - & 30 \\
\hline 92 & 3 & 4 & 1 & 2 & 5 & 6 & 1 & - & - & 1 & 23 \\
\hline 93 & 6 & 2 & 4 & - & 3 & 4 & 3 & - & - & 2 & 24 \\
\hline 94 & 5 & 2 & 3 & 6 & 7 & 4 & 1 & - & - & - & 28 \\
\hline 95 & 2 & 3 & 5 & 1 & 2 & 1 & - & 3 & - & - & 17 \\
\hline 96 & - & - & 4 & 3 & 5 & 6 & 8 & 2 & - & - & 28 \\
\hline 97 & - & 2 & 1 & 2 & 1 & - & 1 & - & - & - & 07 \\
\hline 98 & 2 & 1 & 3 & 5 & 6 & 9 & 8 & 1 & - & - & 35 \\
\hline 99 & 1 & - & 2 & 1 & - & 3 & - & - & - & 1 & 08 \\
\hline 100 & 2 & 1 & 4 & - & 2 & 1 & - & 1 & - & - & 11 \\
\hline Total & 519 & 123 & 449 & 343 & 369 & 404 & 77 & 112 & 02 & 47 & 2,445 \\
\hline
\end{tabular}

Source: Students' essay scripts

The data presented in Table 1 above show that 100 test papers representing $100 \%$ of the total population targeted were examined with the aim to ascertaining the categories or sources of students' errors which this study was concerned with. The figures in the table indicate that out of all the 100 scripts examined, a total of 2,445 different kinds of errors were committed by the participants in this study. This is summarised as follows: 519 errors related to the use of verbs were made by the students; 123 errors related to the use of nouns were identified; 449 errors related to the use of punctuation marks were identified; 343 spelling errors were picked out from the students' scripts; 369 errors were made in relation to the students' use of wrong words or registers or even terminologies; 404 errors were made by the students in relation to the use of capital letters; 77 errors were made in relation to the students' use of pronouns; 112 of the errors were in relation to the use of prepositions; in the area of abbreviations and coinages, 2 errors were identified; and with regards use of article, 47 errors were identified. 
Table 2. Cumulative, frequency and mean scores of the different types of errors identified

\begin{tabular}{lllll}
\hline No & Error Classification & Frequency & Percentage & Mean Score \\
\hline 1 & Verb Usage & 519 & 21.2 & 5.2 \\
\hline 2 & Noun & 123 & 5.0 & 1.2 \\
\hline 3 & Punctuation Marks & 449 & 18.4 & 4.5 \\
\hline 4 & Spellings & 343 & 14.0 & 3.4 \\
\hline 5 & Wrong Words & 369 & 15.1 & 3.7 \\
\hline 6 & Capitalisation & 404 & 16.5 & 4.0 \\
\hline 7 & Pronoun Usage & 77 & 3.1 & 0.1 \\
\hline 8 & Prepositions & 112 & 4.6 & 1.1 \\
\hline 9 & Abbreviations/Coinages & 02 & 0.1 & 0.0 \\
\hline 10 & Articles & 47 & 100 & \\
\hline & Total & $\mathbf{2 , 4 5}$ & & \\
\hline & & & & \\
\hline
\end{tabular}

Source: Students' essay scripts

Table 2 presents the total frequency and mean scores of the various error types found in the students' scripts. The table shows ten (10) categories of errors which were identified in the 100 scripts written by students. The following categories of errors were identified: verb usage, noun, punctuation, spelling, wrong word, capitalisation, pronoun usage, prepositions, abbreviation/coinages and articles. Based on the frequency of error types in the students' scripts, the mean scores were calculated. For all the categories of errors, the mean score is 2.0. An error category that is less than 2.0 is totally not significant but a mean score of 2.0 or above means that the errors are significant.

Looking at the parameters used to determine the level of error significance in the students' scripts, Table 2 reveals that errors associated with the use of verbs has a mean score of 5.2 thereby making verb errors very significant. In terms of errors of noun, a total mean score of 1.2 shows that the errors made with respect to noun usage are not significant. Also, punctuation errors have a mean score of 4.5, and spelling errors show a mean score of 3.4 which are both respectively significant. In the area of wrong word, the total reveals a mean score of 3.7 and for capitalisation, 4.0 indicating that the errors made by the students are significant. With respect to pronoun and preposition usages, a mean score of 0.1 and 1.1 as 
revealed by the table, shows that the errors made with respect to pronoun and prepositions are not significant. Furthermore, the table shows that a mean score of 0.0 for abbreviation/coinages and a mean score of 0.5 for articles are not significant in the students' scripts.

\section{Discussion}

This section presents discussion and analysis of data obtained from the study. For each category of errors identified, the causes or sources of such error category are stated. This study particularly focused on the ten categories of errors identified by the researchers although that does not presuppose the fact that other errors were not found in the 100 scripts. Thus, as a limitation to our study, only errors related to writing among second year students in the Public Health Department were studied.

\subsection{Errors in Verb Usage}

Errors in verb usage constitute the highest recorded category of errors in all of the 100 scripts marked, amounting to 519 which represents $21.2 \%$ and a mean score of 5.2. In actual fact, the students' errors occurred significantly with verbs. Many of the errors in verb usage had to do with subject-verb agreement, conjugation and inappropriate forms. It is clearly indicated in the scripts of the students that most of errors in verb usage emanated from lack of understanding of the grammatical rule of subject-verb agreement. In many instances, singular subjects were matched with plural verbs and vice-visa. It is a grammatical rule that when the verb 'have' is used, the past participle immediately follows; but that was not so in many of the scripts. Below are some instances of verb errors identified.

1. Face masks, which was not something we were accustomed to became one major factor that affected our livelihood.

2. There were no business coming into the country then as boarder were closed.

3. And which I think there is a lot of disadvantages to us and livelihood.

4. Prices has gone up and there is a shortage in production because of lockdown.

\section{This has cause the country economy to drastically lost.}

The error in example 1 has to do with agreement. The plural subject "face masks" is used to agree with the singular verb "was". Also, in example 2, the plural verb "were" was used to agree with the singular subject "business". In sentence 3, the singular verb "is" is used with the plural word "disadvantages". In sentence 4, the plural subject "prices" was used to agree with the singular verb "has". Then in sentence 5, the verb "has" was used with the bare infinitive 'cause' instead of the past participle form 'caused'.

\subsection{Errors in Noun Usage}

In the area of noun usage, 123 errors were identified in the students' scripts. This represents 5\% of all noun related errors and has a mean score of 1.2, which shows that the error is significant. The errors that occurred with nouns involved possessive nouns, singular and 
plural nouns incorrectly formed and subject-verb agreement irregularities. This is exemplified in the underlined grammatical structures below:

6. The corona virus (covid-19) is a very deadly diseases that affect a lot of people.

7. It is a welcoming development that Sierra Leone economy is slowly recovering....

8. One of the best way to control the virus is to put on face mask.

The error in sentence 1 has to do with noun antecedent and numbers. The plural antecedent 'diseases' does not grammatically refer to the singular noun, 'corona virus'. For sentence 2, the error committed is in the area of possession. The correct form should have been, 'Sierra Leone's economy'. Also, in sentence 3, the singular noun 'way' used by students should not have been used. Instead, the plural form 'ways' should have been used.

\subsection{Errors in the Use of Punctuation Marks}

The researchers recorded 449 errors related to punctuation marks, and this accounts for the second highest of all the ten error categories with a percentage of $18.4 \%$ and a mean score of 4.5 , indicating that the errors made by students with respect to the use of punctuation marks were significant. Various punctuation errors were recorded, and below are few examples:

9. In my country Sierra Leone it was mid April when we where about to take an entrance exam.

10. Education, since the Covid-19 outbreak has emerge in Sierra Leone it has affected the education sector by not maintaining the normal functioning of the school, colleges, universities, Most students...

In sentence 9, a comma should have been used after 'Sierra Leone'. Also, in sentence 10, the comma used after 'universities' should have been dropped and replaced with a full stop.

\subsection{Spelling Errors}

Out of the 100 scripts, 343 errors were identified in the area of spellings. Spelling errors represent $14 \%$ and a mean score of 3.4, signaling the fact that the errors made are significant. The following are examples of some spelling errors identified in the students' scripts.

11. There is also a big affection on learning instituations.

12. The economic status in Sierra Leone has become stagnant in the country because noting is moving faster.

The correct spelling for the underlined word in sentence 11 should have been, "institutions". Also, the spelling of the underlined word in sentence 12 is wrong, and it should have been written as 'nothing'.

\subsection{Errors of Wrong Words}

Errors related to the use of wrong words, registers, combination of two separate words and inappropriate expressions amounted to 369 , with a percentage of 15.1 and a total mean score 
of 3.7. This shows that the errors made are significant. This is illustrated below in the sentences below:

13. Sierra Leone is a religious country but because of the outbrake of the covid-19 churches and musque where close.

14. From neighbourhood country will not being coming into our country.

In sentence 13, the candidate should not have used "where" because it is an adverbial form that relates to place and the sentence needed a verb "were" to help establish a sense. Also, in sentence 14, instead of "neighbourhood", it should have been "neighbouring" and instead of "being", it should have been "be".

\subsection{Capitalization Errors}

Errors of capitalization were recorded 404 times in all the scripts and with a percentage of 16.5 and a mean score of 4.0, indicating that the errors are significant. Capitalization errors involved the use of proper nouns, proper adjectives, content words in titles and many of such errors were detected at the beginning of sentences and paragraphs. This is exemplified below:

15. Sierra leone is a country that we know things are not easy with people that are living in the country.

16. thirdly, COVID-19 also, affects our health sector and Doctors, Nurses, CHO's,public health officers were dying in the process to help minimize the outbreak.

17. According to the world bank sierra leone economic update launched in freetown the COVID-19 Pandemic.

In sentence 15 , the candidate should have used a capital ' $L$ ' to start "leone" because it is a word naming a particular country. Also, in sentence 16, the writer should have started with a capital ' $T$ ' instead of the small ' $t$ '. Also, they could have written the proper adjective "health sector" beginning with a capital ' $\mathrm{H}$ ' and ' $\mathrm{S}$ ' but that was omitted. Also, they should not have started the spellings of doctors, nurses with capital letters. Again, they should have used capital ' $\mathrm{W}$ ', 'B', 'S', and 'L' at the beginning of each word in the phrase "world bank sierra leone". Likewise, "freetown" should have started with a capital 'F'.

\subsection{Errors in Pronoun Usage}

This error category recorded a total of 77 occurrences, representing $3.1 \%$ of all the errors committed. Also, it had a mean score of 0.1 , indicating that the errors that occurred with the use of pronouns are not significant. This is illustrated in the examples below.

18. So my best discussion is going to base of how to prevent your selffrom getting the virus.

19. The lock-down had to stop them from provide for theirselves.

20. The exchange of goods or commodities which have been putting food or earning of money by some people which engage them self it has been affected by the covid-19.

From the examples above, we can say the writer of sentence $18 \mathrm{knew}$ which pronoun form to 
use but did not know that the pronoun "yourself" should not be separately written as he did "your self". Moreover, it would have been more appropriate to use "oneself" since the writer is making an indefinite reference. Also, "theirselves" is not correct and does not exist as a pronoun in English. The correct form is "themselves". Similarly, in sentence 20, the forms "them self" and "which" are both inappropriate. They should have been written this way: "themselves" and "who".

\subsection{Errors in the Use of Prepositions}

This category of errors occurred 112, representing $4.6 \%$ and a total mean score of 1.1 . This means that the errors made in the use of prepositions are not significant. Many students have no idea about where, why and when to use certain prepositions. Some of these errors could be seen in the sentences below:

21. After purchasing goods in the provinces it is very difficult to access the city because there are lots of check points on the road which as a result of the covid-19 because people in the check point...

22. This pandemic result to massive increase of prices of goods.

23. Below are some of the effect/or ways I will outline on how covid-19 has affect the livelihoods of people in Sierra leone.

In sentence 21, the candidate should have written "at the check point" instead of "in the check point". Also, in sentence 22, the writer should have used "in" instead of "to". Furthermore, the preposition "on" used in sentence 23 is not appropriate and should never have been used as there is certainly no need for a preposition in that environment.

\subsection{Errors of Abbreviations/Coinages}

There were only 02 errors of abbreviation/coinages identified in the students' scripts. This amounts to 0.1 percent and a mean score of 0.0 , thus indicating the fact that the errors made are not significant. A few examples are given below:

24. nacoverc gave out their guidelines which citizens were to abide by.

25. Government said it will fight the virus paopaly.

In sentence 24, the abbreviation "nacoverc" is not appropriate. This abbreviated form should be written in capital letters. Also, in sentence 25, the world "paopaly" is a coined word that does not exist in English.

\subsection{Errors in the Use of Articles}

There were 47 occurrences of errors related to the use of articles. This represents 1.9 percent of all errors made. This represents a mean score of 0.5 , indicating that the errors made are not significant. This is illustrated below in the sentences.

26. Even some the local business close down due to the high taxation.

27. It is transmitted from an infected person to non-infected person through a respiratory 
droplets.

28. Covid-19 has become a greater problems for different countries such as Italy, America, Germany, Liberia, Guinea, Sierra Leone etc.

29. The COVID-19 set an remarkable awareness to the nation of poor health status.

From the examples given above, we can say that the use of articles is a big challenge to many learners of English. In sentence 26, the article "the" as underlined above is not appropriate and should not have been used at all. In sentence 27 , the article 'a' is used to refer to one entity or item but in the case of the writer of this sentence, the article is seen referring to the plural noun "droplets". Again, in sentence 28, the same article ' $a$ ' is seen referring to a plural noun "problems". In sentence 29 , the article 'an' should not have been used instead the writer should have used the other article 'a'.

\section{Conclusion and Recommendations}

The aim of this study was to analyse grammatical errors in the written essays of students in the Public Health Department of Njala University. From the data collected and analysed, the following grammatical errors were identified: verb usage, noun usage, punctuation marks, spellings, wrong words, capitalisation, pronoun usage, prepositions, abbreviations/coinage and articles. Five categories of errors - verb usage, punctuation marks, spellings, wrong words and capitalisation - were found to be significant as they obtained a mean score of 2.0 and above. The other five error types were insignificant as their mean scores were all below 2.0. This does not however mean that those errors will be ignored in grammar lessons. They can also lead to poor communication or lack of clarity in written sentences.

It could also be concluded that much of these errors came about as a result of interference from the learners' $L_{1}$, overgeneralisation of certain grammatical rules taught, and failure to adequately learn as a result of extra-lingual factors. It is possible that such learners do not interact frequently in English, and as such are not familiar with common acceptable usages. It is also suggests that learners do not have adequate comprehensible input that would enable them perform better in the written form of the language.

Based on the conclusions above, the following recommendations are made in a view to improving the performance of learners of English as a second language:

1. Teachers of English should be encouraged to use the Communicative Language Teaching method, since this method aims at engaging learners in the spoken form of the language. Teachers should encourage learners to develop their writing skills through creative writing exercises.

2. Since certain English words are very difficult to spell as a result of the irregular English spelling system, teachers should ensure they give their learners sufficient practice in the English spelling rules.

3. Learners must also be encouraged to read other texts apart from the ones prescribed for them. It is possible that during their extra reading they can come across new words and 
expressions which will help them in their writing.

4. Teachers of English need to be up to the task in the teaching of English. Although the study did not investigate the role of teachers in the teaching and learning of English, it is highly likely that induced errors may have a part to play in the preponderance of errors in the writing of students. There is evidence that a good number of lecturers do not communicate with their students in English, but rather prefer to use Krio - a lingua franca in Sierra Leone. This makes students not to think in English when they are writing.

5. Efforts must be made to conduct remedial classes, as some of the classes are too large making it difficult for teachers to concentrate on all their learners.

\section{Acknowledgments}

We did not receive any financial support to carry out this study. It was entirely funded by the researchers. We will however like to thank the students who willingly gave their consent to write the essays that we used for the analysis. We also thank the Head of Department who granted us permission to conduct the test using students in his department.

\section{References}

Abushihab, I. (2014). An Analysis of Grammatical Errors in Writing Made Turkish Learners of English as a Foreign Language. International Journal of Linguistics, 6(4), 213-223.

Al-Khresheh, M. H. (2016). A Review Study of Error Analysis Theory. International Journal of Humanities and Social Science Research, 2(2), 49-59.

Corder, S.P. (1967). The significance of learners' errors. International Review of Applied Linguistics, 5, 160-170.

Feltsen, P. (2009). Language Acquisition and the Errors we Make. Mittuniversitetet. Mid Sweden University.

Gomina, K. (2014) Influence of SMS Grammar on the Written English of Students in Nigeria. Journal of General Studies in Education, 2(1), 168-177.

Gut, U. (2013). Standards of English in West Africa. Retrieved 14 October 2021, from https://www.cambridge.org/core/books/abs/standards-of-english-I-west-africa

Jabeen, A. et al.. (2015). The Role of Error Analysis in Teaching and Learning of Second and Foreign Language. Education and Linguistics Research, 1(2).

James, C. (2001). Errors in Language Learning and Use: Exploring Error Analysis. Beijing: Foreign Language Teaching and Research Press.

Keshavarz, M. H. (2013). Contrastive and Error Analysis. Tehran, Rahnama Press.

Khansir, A. A. (2012). Error Analysis and Second Language Acquisition. Theory and Practice in Language Studies, 2(5), 1027-1032.

Lado, R. (1957). Linguistics Across Cultures. Ann Arbor: University of Michigan Press. 


\section{Macrothink}

International Journal of Linguistics

ISSN 1948-5425 2022, Vol. 14, No. 1

Lagu, S. A. (2019). Grammatical Errors in the Expository Essays of Public Administration Students of Adamawa State University, Mubi. Research Journal of English Language and Literature, 7(1), 181-192.

Nemser, W. (1971). Approximative Systems of Foreign Language Learners. International Review of Applied Linguistics, 9, 115-123.

Pouladian, N., Bagheri, M. S., \& Sadighi, F. (2017). An Analysis of Errors in Writing Skills of Adult Iranian Learners Preparing for IELTS. International Journal of English Linguistics, 7(3), 85-96.

Selinker, L. (1972). Interlanguage. International Review of Applied Linguistics, 10, 209-231.

Sermsook, K., Liamnimitr, J. \& Pochakorn, R. (2017). An Analysis of Errors in Written English Sentences: A Case Study of Thai EFL Students. English Language Teaching, 10(3), 101-110.

Sowa, M. (2017). Common Errors in Writing among Senior Secondary School Pupils: A Case Study of three Schools in Freetown. Unpublished Master dissertation, Njala University, Sierra Leone.

Udom, G. I. (2014). Towards Improving the Teaching of English Language and Communication Skills in Nigerian Colleges of Education. Journal of General Studies in Education, 2(1), 97-104.

Valcea, C. A. (2020). First Language transfer in second language acquisition as a cause for error making in translation. Diacronia.

\section{Copyrights}

Copyright for this article is retained by the author(s), with first publication rights granted to the journal.

This is an open-access article distributed under the terms and conditions of the Creative Commons Attribution license (http://creativecommons.org/licenses/by/4.0/) 